\title{
PEMANFAATAN TUMBUHAN BAWAH SEBAGAI OBAT OLEH MASYARAKAT SEKITAR HUTAN TAMAN HUTAN RAYA SULTAN THAHA SYAIFUDDIN PROVINSI JAMBI
}

\section{(Utilization of Understrorey Plants as Drugs by Communities Around Sultan Thaha Syaifuddin Forest Garden Jambi Province)}

\author{
Albayudi $^{1}$, Zuhratus Saleh $^{1}$ \\ ${ }^{1)}$ Fakultas Kehutanan Universitas Jambi \\ Jl. Raya Jambi-Ma.Bulian KM.15, Mendalo Indah, 36361 \\ E-mail:yudia.bch@gmail.com,zuhratussaleh@ymail.com
}

Diterima: 14 Februari 2020, Direvisi: 20 Maret 2020, Disetujui: 20 Maret 2020

DOI: https://doi.org/10.31849/forestra

\begin{abstract}
In some conservation forest areas, interaction between local communities and natural resources is still very strong. The people who live around Taman Hutan Raya Sultan Thaha Syaifuddin Jambi Province (Tahura STS Jambi) are known to still use some species of plants for medicinal purposes. The tradition and knowledge of local people in the rural areas about the use of plants to meet their daily needs has been going on for a long time even before an area is designated as conservation forest. The purpose of this study was to inventory the species of plants that are used as medicine by the community around Tahura STS Jambi, especially the understorey. This research was conducted at Tahura STS Jambi in July-September 2018. The method used in this study were interviews and surveys directly in the field so we only documented every kind mentioned by the informants and has a presence in the field. The results of the study showed that 22 lower-level plants were used as medicine by the community around Tahura. These plants are used as medicine for various medical and non-medical diseases. This small number of species is considered as an indicator of decreased knowledge and utilization of medicinal plants by communities around the forest.
\end{abstract}

Keywords : Communities around forest, Conservation, Medicinal Plant,

\begin{abstract}
ABSTRAK
Pada beberapa kawasan hutan konservasi , interaksi antar masyarakat lokal dengan sumber daya alam masih sangat kuat. Masyarakat yang tinggal di sekitar Taman Hutan Raya Sultan Thaha Syaifuddin Provinsi Jambi (Tahura STS Jambi) diketahui masih memanfaatkan beberapa jenis tumbuhan untuk keperluan obat. Tradisi dan pengetahuan masyarakat lokal di daerah pedalaman tentang pemanfaatan tumbuhan untuk memenuhi kebutuhan sehari-hari telah berlangsung sejak lama bahkan sebelum suatu kawasan ditetapkan sebagai hutan konservasi. Tujuan penelitian ini adalah untuk mengiventarisasi jenis tumbuhan yang dimanfaatkan sebagai obat oleh masyarakat sekitar Tahura STS Jambi khususnya tumbuhan bawah. Penelitian ini dilakukan di Tahura STS Jambi pada bulan Juli-September 2018. Metode yang digunakan dalam penelitian ini adalah wawancara dan survey langsung di lapangan sehingga yang didokumentasikan hanya setiap jenis yang disebutkan informan dan dapat ditemukan
\end{abstract}


keberadaannya di lapangan. Dari hasil penelitian ditemukan 22 jenis tumbuhan tingkat bawah yang dimanfaatkan sebagai obat oleh masyarakat sekitar Tahura. Tumbuhan tersebut dimanfaatkan sebagai obat dari berbagai penyakit baik medis maupun non medis. Jumlah jenis yang sedikit ini dianggap segagai indikator menurunnya pengetahuan dan pemanfaatan tumbuhan obat oleh masyarakat sekitar hutan.

Kata Kunci : Konservasi, Masyarakat Sekitar Hutan, Tumbuhan Obat.

\section{PENDAHULUAN}

Tahura Sultan Thaha Syaifuddin adalah salah satu tahura di Indonesia yang berada di Kabupaten Batanghari, Provinsi Jambi. Tahura Sultan Thaha Syaifuddin didirikan berdasarkan surat keputusan Menteri Kehutanan Nomor: 94/ kpts-III/ 2001. Pertimbangan ditetapkannya wilayah ini menjadi Tahura yaitu untuk melindungi flora atau fauna eksotik dan endemik yang mendekati kepunahan. Tahura Sultan Thaha Syaifuddin dikenal karena ciri khasnya yaitu habitat dari tumbuhan Bulian (Eusideroxylon zwageri) yang terdapat di dalam kawasan. Tahura Sultan Thaha Syaifuddin secara wilayah administratif dikelilingi oleh beberapa Desa yaitu: Desa Bungku, Pompa Air, Mekar Jaya, Singkawang, Tenam, Jebak, Ampelu, Jangga Baru, Bulian Baru dan Kelurahan Sridadi (Budiandrian et al., 2017).

Pada beberapa kawasan hutan lindung dan konservasi, interaksi antar masyarakat lokal dengan sumber daya alam masih sangat kuat. Bahkan di beberapa lokasi, pola interaksi yang terjalin memberikan kecenderungan positif terhadap kelestarian hutan. Seperti halnya Tahura Sultan Thaha Syaifuddin (STS) yang merupakan kawasan hutan konservasi yang seharusnya perlu dijaga dan dipertahankan secara lestari. Interaksi masyarakat sekitar dengan hutan merupakan upaya pemenuhan kebutuhan hidup karena masyarakat sekitar hutan biasanya memiliki kearifan lokal dalam kegiatan pemanfaatan sumber daya alam (Lewerissa, 2015).

\section{Menurut Pulunggono (1999),} masyarakat tradisional dan modern hingga saat ini masih banyak menggunakan tumbuhan yang bersumber dari alam yang sebagian besar merupakan tumbuhan potensial. Mengingat pemanfaatannya yang sangat strategis dalam menunjang pembangunan di masa kini dan masa mendatang. Tradisi dan pengetahuan masyarakat lokal di daerah pedalaman tentang pemanfaatan tumbuhan untuk 
memenuhi kebutuhan sehari-hari telah berlangsung sejak lama. Pengetahuan ini dimulai dengan dicobanya berbagai tumbuhan untuk memenuhi kebutuhan hidup (Windadri, Rahayu \& Rustiami 2006).

Pada era Millenium ini, kecenderungan gaya hidup masyarakat dunia adalah back to nature. Hal ini mengakibatkan penggunaan metode tradisional tidak akan ketinggalan zaman. Di dunia barat, walaupun masyarakatnya telah berpikiran dan berbudaya dengan sangat maju dan modern, sampai sekarang ini kecenderungan untuk menggunakan metode pengobatan atau terapi untuk suatu penyakit dengan metode pengobatan tradisional tetap masih ada. Bahkan ada indikasi terjadinya peningkatan dalam hal penggunaan obat tradisional (Dianawati et al., 2001).

Penelitian mengenai pemanfaatan tumbuhan dalam Tahura STS oleh masyarakat sekitar telah dilakukan tetapi kebanyakan berfokus pada perambahan dan pemanfaatan potensi kayu. Padahal tahura juga menyimpan keanekaragaman tumbuhan dan pemanfaatannya oleh masyarakat sekitar tahura. Secara umum, tumbuhan bawah merupakan tumbuhan yang paling banyak digunakan masyarakat. Penelitian ini secara khusus bertujuan untuk mengeksplorasi pengetahuan lokal masyarakat sekitar Tahura STS mengenai jenis tumbuhan bawah yang dimanfaatkan dan diambil dari Tahura STS.

\section{METODE PENELITIAN}

Penelitian ini dilakukan pada bulan Maret-September 2018 dengan lokasi penelitian di Taman Hutan Raya Sultan Thaha Syaifudin (Tahura STS) Provinsi Jambi. Pengumpulan data dilakukan secara langsung melalui eksplorasi lapangan berdasarkan hasil wawancara dengan masyarakat sekitar Tahura. Spesies tumbuhan yang ditemukan keberadaannya kemudian diambil sampelnya untuk dibuat menjadi specimen herbarium dan diketahui nama ilmiahnya. Analisis data dilakukan secara deskriptif berdasarkan hasil wawancara, survey lapangan dan studi literatur yang relevan.

\section{HASIL DAN PEMBAHASAN}

Secara administratif Taman Hutan Raya (Tahura) Sultan Thaha Syaifuddin terletak di Kabupaten Batanghari Provinsi 
Jambi. Secara geografis wilayah Taman Hutan Raya Sultan Thaha Syaifuddin terletak antara $1^{\circ} 47^{\prime} 55^{\prime \prime}-1^{\circ} 57^{\prime} 31^{\prime \prime}$ LS dan $103^{\circ} 08^{\prime} 30^{\prime \prime}-103^{\circ} 16^{\prime} 40^{\prime \prime}$ BT. Dengan keadaan topografi berupa daerah perbukitan dengan ketinggian berkisar antara 11-500 m diatas permukaan laut dengan bentang lahan sebagian bergelombang dan sebagian datar. Rata-rata curah hujan bulanan berkisar antara $175 \mathrm{~mm}$ sampai $222 \mathrm{~mm}$ dengan suhu udara harian rata-rata $28{ }^{\circ} \mathrm{C}$. Jenis tanah yang dominan adalah podsolik merah kuning (70\%), sebagian alluvial (18\%), granosol (3.24\%) dan lainnya $(8.58 \%)$. Kawasan Tahura Sultan Thaha Syaifuddin masuk ke dalam empat wilayah kecamatan, yaitu Kecamatan Muara Bulian, Kecamatan Bajubang, Kecamatan Muara Tembesi dan Kecamatan Batin XXIV. Kondisi yang masih berhutan tinggal $10 \%$ dari luasan Tahura terletak di pal 15 sekitar kantor unit pelayanan terpadu (UPTD) Tahura (Dinas Kehutanan Kabupaten Batang Hari, 2016). Kawasan hutan Taman Hutan Raya Sultan Thaha Syaifuddin telah dirambah oleh masyarakat sebagai lahan pertanian dan perkebunan. Lahan perkebunan karet dan sawit yang terdapat hampir mencapai $70 \%$ dari luasan Tahura.
Lahan kritis sekitar $18 \%$ dari luasan kawasan akibat kebakaran hutan dan lahan yang sengaja dibakar oleh masyarakat untuk membuka lahan perkebunan oleh pihak pemangku kepentingan. Pada kawasan Tahura juga terdapat pemukiman penduduk sekitar 2\% dari luasan kawasan tahura, selain itu kondisi mata air seperti danau dan rawa telah dikeliling oleh kondisi hutan kritis dan rusak (Budiandrian et al., 2017).

Eksplorasi dan inventarisasi tumbuhan obat dilakukan pada bulan Mei Agustus 2018 di Tahura Sultan Thaha Syaifuddin. Kegiatan ini dilakukan dengan cara pengamatan langsung di lapangan dan membawa masyarakat lokal yang dianggap mengetahui dan memanfaatkan tumbuhan obat. Dari tabel 1 terlihat bahwa dalam eksplorasi ini ditemukan 22 jenis tumbuhan obat yang dimanfaatkan masyarakat sekitar tahura STS. Beberapa sudah diketahui nama latinnya tetapi beberapa lainnya masih dalam proses identifikasi di herbarium. Tumbuhan obat yang didapatkan ini merupakan tumbuhan yang tumbuh di alam dan dimanfaatkan langsung oleh masyarakat. Pada tabel 1 tersebut juga terlihat bahwa berbagai variasi penyakit 
dapat disembuhkan dengan tumbuhan obat dari alam. Pada tabel tersebut dapat dilihat pula bahwa daun merupakan bagian tumbuhan yang paling banyak dimanfaatkan sebagai obat. Pemanfaatannya pun bervariasi mulai dari rebusan, digosok ke tubuh, diremas dan dimandikan ke tubuh. Akar,umbi dan bunga juga dimanfaatkan tetapi pemanfaatannya tidak sebanyak daun.

Tabel 1. Jenis Tumbuhan yang Dimanfaatkan Sebagai Obat Oleh Masyarakat Sekitar Tahura STS Jambi

\begin{tabular}{|c|c|c|c|}
\hline $\begin{array}{l}\mathrm{N} \\
\mathrm{o} .\end{array}$ & $\begin{array}{l}\text { Nama } \\
\text { Tumbuhan }\end{array}$ & $\begin{array}{l}\text { Bagian yang } \\
\text { Digunakan }\end{array}$ & $\begin{array}{l}\text { Kegunaaan/ } \\
\text { Khasiat }\end{array}$ \\
\hline 1. & $\begin{array}{l}\text { Puar } \\
\text { (Etlingera } \\
\text { elatior) }\end{array}$ & Bunga & Obat Malaria \\
\hline 2. & Gayat & Daun & Obat Asma \\
\hline 3. & $\begin{array}{l}\text { Salung } \\
\text { (Psychotri } \\
\text { a } \\
\text { viridiflora } \\
\text { ) }\end{array}$ & Daun & $\begin{array}{l}\text { Obat untuk } \\
\text { melahirkan }\end{array}$ \\
\hline 4. & $\begin{array}{l}\text { Amplas } \\
\text { kijang }\end{array}$ & Batang & Obat Batuk \\
\hline 5. & $\begin{array}{l}\text { Daun } \\
\text { sanjaga }\end{array}$ & Daun & $\begin{array}{l}\text { Obat } \\
\text { menghilangk } \\
\text { an } \\
\text { mengantuk }\end{array}$ \\
\hline 6. & Semobi & Daun muda & $\begin{array}{l}\text { Obat Pusing } \\
\text { kepala }\end{array}$ \\
\hline 7. & $\begin{array}{l}\text { Kebasau } \\
\text { hitam }\end{array}$ & Daun & Obat Batuk \\
\hline 8. & $\begin{array}{l}\text { Kelalait } \\
\text { (Uncaria } \\
\text { acida) }\end{array}$ & Akar & Obat Mual \\
\hline 9. & $\begin{array}{l}\text { Pasak } \\
\text { bumi } \\
\text { Eurycoma } \\
\text { longifolia } \\
\text { Jack) }\end{array}$ & Akar & $\begin{array}{l}\text { Obat anti } \\
\text { hipertensi, } \\
\text { obat sakit } \\
\text { perut, obat } \\
\text { kuat bagi } \\
\text { pria dewasa. }\end{array}$ \\
\hline
\end{tabular}

\author{
10 Lempuyan Umbi \\ g/ Kunyit \\ rimbo \\ 11 Tembuli \\ Daun
}

12 Sepempan Akar

13 Seduduk/ Keduduk (Melastom a candidium )

14 Penyanit/ Segitiga

15 Puar sulung

16 Mantobun g 17 Lengkuas

18

Ketepeng ( Casia alata. L)

19 Jeruk hutan (Triphasia trifolia)

20 Melati hutan

21 Sindai

Daun

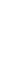

Batang,

Pucuk daun

Pucuk daun

Daun

Daun

Daun

Buah

Obat pusing

kepala

Obat Batuk

Obat mata merah Obat Pusing kepala

Obat

Demam

dingin

Obat kulit$$
\text { . }
$$

22 Kayas

Akar

Daun

Obat pusing

kepala

Obat

menghentika

$\mathrm{n}$

pendarahan

Obat

penyakit

Maagh/

Lambung

Pemanfaatan tumbuhan langsung dari alam masih menjadi tumpuan bagi jutaan penduduk dunia. Untuk tumbuhan obat saja diperkirakan terdapat 70.000 spesies yang berpotensi obat (Hawkins, 2008). Banyaknya pemanfaatan ini 
seringkali dijadikan dasar dalam mengembangkan jenis obat tertentu karena sekitar 50.000 jenis tumbuhan diperkirakan berpotensi obat berdasarkan berbagai studi (Schippman et al., 2002). Jumlah sebanyak itu jika dibandingkan adalah sekitar $20 \%$ dari total tumbuhan berpembuluh yang diketahui di seluruh dunia dan hal tersebut menggambarkan betapa luasnya tumbuhan dan keanekaragaman hayatinya yang dimanfaatkan oleh manusia (Hamilton et al., 2006).

Beberapa jenis yang ditemukan terbukti bermanfaat secara medis dan telah diteliti di dalam dan luar negeri. Puar (Etlingera elatior) misalnya, merupakan salah satu anggota family Zingiberaceae (jahe-jahean) yang banyak ditemukan di Indonesia. Hampir semua masyarakat di berbagai daerah di Indonesia telah memanfaatkan jenis ini sebagai bahan masakan. Jenis ini juga dapat dimanfaatkan sebagai bahan dasar kertas (Heyne, 1987) serta berpotensi sebagai antioksidan (Jackie et al, 2011) dan memiliki efek protektif (Haleagrahara et al, 2010). Demikian juga dengan jenis Salung (Psychotria viridiflora). Jenis ini merupakan anggota family Rubiaceae yang sering ditemui di hutan sekunder. Pada lokasi penelitian, jenis ini dimanfaatkan sebagai obat untuk melahirkan. Jenis ini sudah diteliti lebih lanjut dalam berbagai penelitian seperti potensi etnofarmakologi (Calixto, et al, 2016), Pewarna natural (Ngo et al., 2013) dan Uji aktivitas bioaktif (Salni et al., 2018)

Pada beberapa kawasan hutan lindung dan konservasi, interaksi antar masyarakat lokal dengan sumber daya alam masih sangat kuat. Bahkan di beberapa lokasi, pola interaksi yang terjalin memberikan kecenderungan positif terhadap kelestarian hutan. Interaksi masyarakat sekitar dengan hutan merupakan upaya pemenuhan kebutuhan hidup. Masyarakat sekitar hutan biasanya mempunyai pengetahuan terkait pemanfaatan alam dan akan terus berubah menyesuaikan diri sebagaimana hutan sekitarnya juga mengalami perubahan (Ulfa, 2014).

Jenis-jenis yang dimanfaatkan dari dalam Tahura STS ini secara umum termasuk kepada jenis dengan penyebaran yang luas dan tidak terbatas hanya ada di dalam kawasan hutan saja. Hal senada juga diungkap Hariyadi (2011) bahwa jenis-jenis tumbuhan yang banyak dimanfaatkan 
sebagai tumbuhan obat bukanlah berasal dari hutan alam, melainkan dari ekosistem yang sudah banyak mendapat sentuhan manusia (human made ecosystem), khususnya semak belukar dan kawasan perladangan. Sebenarnya hutan tropika Indonesia yang terdiri dari berbagai tipe ekosistem merupakan gudang keanekaragaman hayati dimana lebih dari 2.039 jenis tumbuhan obat dapat ditemukan di kawasan ini yang berguna untuk menyehatkan dan mengobati berbayang berguna untuk menyehatkan dan mengobati berbagai macam penyakit manusia maupun hewan ternak (Zuhud, 2009).

\section{KESIMPULAN DAN SARAN}

\section{A. Kesimpulan}

Penelitian yang telah dilakukan ini mendapatkan kesimpulan bahwa terdapat 22 jenis tumbuhan yang dimanfaatkan masyarakat sekitar Tahura Sultan Thaha Syaifuddin Jambi sebagai tumbuhan obat. Tumbuhan obat dipakai untuk penyakit medis dan non medis. Daun menjadi organ tumbuhan yang paling banyak dimanfaatkan sebagai obat.

\section{B. Saran}

Penelitian ini nantinya di masa akan dapat mengambil data sosial ekonomi masyarakat di sekitar Tahura STS agar lebih menguatkan alasan pemanfaatan tumbuhan hutan.

\section{UCAPAN TERMA KASIH}

Penelitian ini terlaksana berkat bantuan dana DIPA Fakultas Kehutanan Universitas Jambi Tahun 2018. Terimakasih juga untuk kerjasama Dinas Lingkungan Hidup Kabupaten Batanghari serta mahasiswa yang membantu jalannya penelitian.

\section{DAFTAR PUSTAKA}

Calixto. N. O., Pinto. M. E. F., Ramalho. S.D., Burger .M. C. M., Bobey. A. F., Young. M. C. M., Bolzani. V. S., and Pinto. A. C. 2016.The Genus Psychotria: Phytochemistry, Chemotaxonomy,

Ethnopharmacology and Biological Properties. J. Braz. Chem. Soc.. 27(8) : 1355-1378

Dianawati, A. dan Irawan, E.S. 2001. Ramuan Tradisional. Cetakan Kedua. PT Agro Media Pustaka. Jakarta

Dinas Kehutanan Kabupaten Batang Hari. 2016. Laporan Akuntabilitas Kinerja. Dinas Kehutanan 
Kabupaten Batang Hari. Muara Bulian.

Djauhariya, E dan Hernani. 2004. Gulma Berkhasiat Obat. Cetakan I. Jakarta: Penebar Swadaya.

Haleagrahara $\mathrm{N}^{1}$, Jackie $\mathrm{T}$, Chakravarthi $\mathrm{S}$, Rao M, Kulur A. 2010. Protective effect of Etlingera elatior (torch ginger) extract on lead acetate-induced hepatotoxicity in rats. $\underline{J}$ Toxicol Sci. 35(5):663-71.

Hamilton A., Dürbeck, K. \& Lawrence, A., 2006. Towards a Sustainable Herbal Harvest. Plant Talk, 43:3235 .

Hariyadi, B. (2011). Obat Rajo Obat Ditawar: Tumbuhan Obat dan Pengobatan Tradisional Masyarakat Serampas - Jambi. Jurnal Biospecies. 4 (2): 29 - 34.

Hawkins, B., 2008. Plants for life: Medicinal plant conservation and botanic gardens. Botanic Gardens Conservation International, Richmond, U.K.

Heyne, K. 1987. Tumbuhan Berguna Indonesia. Jilid I dan II. Terj. Badan Libang Kehutanan. Bogor.

Jackie, T., Haleagrahara, N., and Chrakravharti, S. 2011. Antioxidant effects of Etlingera elatior flower extract against lead acetate - induced perturbations in free radical scavenging enzymes and lipid peroxidation in rats. BMC Res Notes 4:67 doi: 10.1186/1756-0500-4-67
Lewerissa E. 2015. Interaksi Masyarakat Sekitar Hutan Terhadap Pemanfaatan Sumber Daya Hutan di Desa Wangongira, Kecamatan Tobelo Barat. Jurnal Agroforestri X (1) :11-20.

Martin GJ. 1998. Etnobotany, A People and Plants Conservation Manual. Maryati Mohamed, penerjemah. London: Chapman and Hall.

Ngo JSK, Ong WF, Ahmad FB, Bujang KB. 2013. A Study of SolublePowdered Natural Dyes.Research Journal of Textile and Apparel17(1): 104-112,

Pulunggono HB. 1999. Ethnobotany of people live in Amarasi of Kupang, Maulo, and Amariti of South Central Timor, West Timor, Indonesia. Media Konservasi 6 (1): 21-35.

Purwanto Y, Waluyo EB. 1992. Etnobotani Suku Dani di Lembah BaliemIrian Jaya : Tinjauan terhadap pengetahuan dan pemanfaatan sumberdaya alam tumbuhan. Prosiding Seminar dan Lokakarya Nasional Etnobotani. CisaruaBogor, 19-20 Februari 1992. Bogor: Departemen Pendidikan dan Kebudayaan RI, Lembaga Ilmu Pengetahuan Indonesia, Perpustakaan Nasional RI. Hal 132-148.

Salni .S, Hanifa, M., Harmida, H. 2018. Activity Tests of Bioactive Material of Salung Leaf (Psychotria viridiflora Reinw. Ex. Blume) against Salmonella thypi 
Bacteria In Vitro And In

Vivo.Jurnal Ilmu Kefarmasian

Indonesia. 4(1) : 13-18

Schippmann, U., Leaman, D., Cunningham, A., 2002. Impact of cultivation and gathering of medicinal plants on biodiversity: Global trends and issues. FAO, Rome, Italy.

Ulfa, M. 2014. Pengetahuan dan perubahan pengetahuan petani hutan rakyat dalam mencapai pengelolaan hutan lestari.(tesis). Sekolah Pascasarjana Institut Pertanian Bogor. Bogor.

Windadri FI, Rahayu M, Rustiami H. 2006. Pemanfaatan tumbuhan sebagai bahan obat oleh masyarakat lokal suku Muna di Kecamatan Wakarumba, Kabupaten Muna, Sulawesi Utara. Biodiversitas. 7 (4): 333-3

Zuhud EAM. 2009. Potensi Hutan Tropika Indonesia Sebagai Penyangga Bahan Obat Alam Untuk Kesehatan Bangsa. Jurnal Bahan Alam Indonesia 6 (6): 227-232 